\section{Birlesik Dünya Arastrma Cypriot Journal of Educational BD-CENTER \\ Sciences}

Innovasyon ve Yayıneılık Merkezi
Volume 15, Issue 6, (2020) 1642-1658

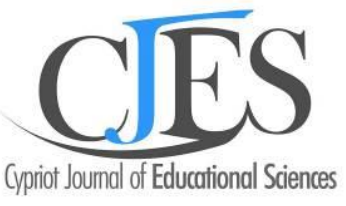

www.cjes.eu

\title{
Motivation and commitment of English student teachers of some Universities in Indonesia
}

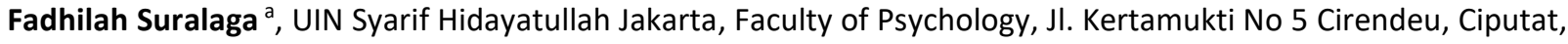
Tangerang Selatan, Banten, ID 15419, Indonesia

Siti Nurul Azkiyah b*, UIN Syarif Hidayatullah Jakarta, Faculty of Educational Sciences, JI. Ir. H. Juanda No.95, Tangerang Selatan, Banten, ID 15411, Indonesia

Rumtini Rumtini c, Universitas Sebelas Maret, Fakultas Sosial Budaya, Jl. Ir. Sutami No. 36A Kentingan, Jebres, Surakarta, Jawa Tengah, Indonesia

Yenny Rahmawati d, UIN Syarif Hidayatullah Jakarta, Faculty of Educational Sciences, Jl. Ir. H. Juanda No.95, Tangerang Selatan, Banten, ID 15411, Indonesia

Yunita Faela Nisa e, UIN Syarif Hidayatullah Jakarta, Faculty of Psychology, Jl. Kertamukti No 5 Cirendeu, Ciputat, Tangerang Selatan, Banten, ID 15419, Indonesia

\section{Suggested Citation:}

Suralaga, F., Azkiyah, S.N., Rumtini, R., Rahmawati, Y., \& Nisa, Y.F. (2020). Motivation and commitment of English student teachers of some Universities in Indonesia. Cypriot Journal of Educational Science. 15(6), 1642-1658. https://doi.org/10.18844/cjes.v15i6.5323

Received from July 25, 2020; revised from October 19, 2020; accepted from December 22, 2020.

${ }^{\circ} 2020$ Birlesik Dunya Yenilik Arastirma ve Yayincilik Merkezi. All rights reserved.

\begin{abstract}
Teachers play crucial roles; therefore, this study is intended to examine student teachers' motivation (instrumental vs. integrative) and commitment (committed passionate, committed compromiser, undecided and uncommitted) to teaching. Quantitative approach using a questionnaire was conducted involving 328 English student teachers from some universities in Indonesia. Using the descriptive analysis, the findings show that those having integrative motivation are $56 \%$ and the highest figure for the level of commitment is, as expected, committed passionate (44\%). Concerning gender differences, more males (M: $60 \%, F: 55 \%)$ were surprisingly found to have integrative motivation, although more females were found to have the highest level of commitment (M: 35\%, F: 47\%). These findings at the same time reveal a considerably high proportion of those who did not have a genuine motive to enroll in a teacher education programme and to commit to becoming teachers implying necessary measures from both the government and the teacher education institutions.
\end{abstract}

Keywords: Commitment, motivation, student teacher, teacher, teacher education.

\footnotetext{
* ADDRESS FOR CORRESPONDENCE: Siti Nurul, Azkiyah, Affiliation, UIN Syarif Hidayatullah Jakarta, Faculty of Educational Sciences, JI. Ir. H. Juanda No.95, Tangerang Selatan, Banten, ID 15411, Indonesia

E-mail address: Azkiyah@uinjkt.ac.id Tel.: +62-813-1463-3028
} 


\section{Introduction}

Teachers are considered as crucial parts of education because they are the most determining factor for student performance (Creemers \& Kyriakides, 2008; Muijs \& Reynolds, 2011). This can be true since teachers assist their students with knowledge, understanding and skills (Bruinsma \& Canrinus, 2012; Low, Lim, Ch'ng \& Goh, 2011). Furthermore, teachers enable students to experience and to benefit the learning processes that help them to achieve their learning goals as well as influence their emotional states.

For the above-mentioned reasons, careful attention should be given to the future teachers entering teacher education. Some research on student teachers have been conducted in Indonesia (Astika, 2014; Azkiyah \& Mukminin, 2017; Masbirorotni et al., 2020), Singapore (Low, Ng, Hui \& Cai, 2017), Hong Kong and Macau (Tang, Wong, Wong \& Cheng, 2018), Austria, Germany and Switzerland (Konig, Rothland, Tachtsoglou \& Klemenz, 2016), which has focused on motivation, commitment, refection, challenges and pedagogical competence. These research studies indicate that motivation is one of the most important factors influencing education.

In the context of Indonesia, where this study was conducted, student teachers' motivation is both important and interesting since the Indonesian government launched a teacher certification programme in 2007, which has attracted a lot of high school graduates to enroll in teacher education institutions. Masbirorotni et al. (2020), for instance, have noted that as many as 300,000 teacher candidates are produced each year while the country requires only about 40,000 teachers, and hence there is an oversupply of teacher candidates. Up until now, as reported by Masbirorotni et al. (2020), there are not many studies investigating student teachers' motivation in enrolling in teacher education faculties. Thus, it is crucial to carry out a study on student teachers' motivation to enroll in teacher education institutes including those who have registered in the English Education Department, which is the focus of this study.

Motivation has been largely related to psychological science, in which concept varies from one expert to others. It has been generally understood as energy or drive that triggers somebody to do something naturally (Jiying \& Hongbiao, 2016). Especially connected with the job market, Pinder (1998, p. 11) viewed that 'work motivation is a set of energetic forces that originates both within as well as beyond an individual's being, to initiate work-related behaviour, and to determine its form, direction, intensity, and duration'. Concerning language learning, which is related to this paper, Ellis (1994) defined motivation as attempts by language learners due to the need and desire to learn the language.

Concerning the types, the literature on motivation has most of the time referred to the work of Deci (1975) and Gardner and Lambert (1972). Deci (1975, p. 24) has argued that there are two main types of motivation, which are intrinsic and extrinsic. Intrinsically motivated learners have 'internally rewarding consequences' due to the 'feeling of competence and self-determination'. Different from this, extrinsically motivated students have in their minds certain rewards such as diplomas, prizes and good marks. In other words, those who have intrinsic motivation do something because they are interested in the activity or enjoy doing it, while extrinsically motivated students like to do something because of some external compensations.

Quite similar to these two types of motivation, a few years previously, Gardner and Lambert (1972) identified integrative and instrumental motivation, especially with regard to language learning. Integrative motivation concerns students who wish to integrate into the target culture, while 
instrumental motivation refers to goals in achieving certain rewards such as a promotion or good grades. In the context of the teaching profession, integrative motivation includes some factors that arise internally from individuals' hearts, such as enjoyment of teaching, job satisfaction, creativity and an interest in teaching the subject matter. On the contrary, instrumental motivations are related to some external elements outside the work itself, such as the prestige of the occupation, better salary and vacancies, as well as job guarantee, transferability and flexibility.

Concerning student teachers of the English Education Department as the subjects of this study, motivation is related to the motivation of individuals to become English teachers and therefore enrol in English Education Department. Various studies have been conducted to examine student teachers' motivation because motivation, especially the integrative one is a strong driving force encouraging student teachers' decision to choose to be a teacher as their future career (Raufelder \& Hoferichter, 2015). This is in line with what Gardner and Lambert (1972) have argued long ago that integrative motivation is a major contributor and a key driver of successful language learning compared to instrumental motivation.

In Asian countries, the study conducted by Low, Lim, Ch'ng and Goh (2011) in Singapore reveals that the number of those having intrinsic motivation is higher, in which the highest two reasons are the participants' interest in teaching and love for children. Similarly, Teh, Sulaiman and Yusoff (2018) also found that in the context of Arabic teaching, the dominant motivation among the student teachers in the Arabic Department in Malaysia is integrative motivation.

In Indonesia, where this study was conducted, some studies on pre-service teachers have been carried out but more on other sectors using reflective teaching as a different way of assessing student teachers in teacher education institutions (Astika, 2014) and the teaching performance of English Education Department students (Azkiyah \& Mukminin, 2017). Studies related to pre-service teachers' motivation, especially with regard to those in universities under the Ministry of Education and Culture (MoEC) and those in the Ministry of Religious Affairs (MoRA) as the two ministries managing education in Indonesia are limited. Both types of universities run quite a similar curriculum but universities under the Ministry of Religious Affairs offers some content of Islamic teaching and has opened various religious departments run by different faculties. Hence, not much is known about the motive of pre-service teachers enrolling in teacher education programmes in the universities under MoRA and its comparison with another type of university in Indonesia.

In addition to motivation, one of the most up-to-date and extensively referred to studies is Heinz's (2015) study, an international review of empirical studies on student teachers, which findings indicate that commitment is a crucial factor to consider. This commitment has been previously regarded to be a determining factor affecting teacher's job satisfaction and retention (Klassen \& Chiu, 2011) and the intention of student teachers to join the teaching profession (Rots, Aelterman \& Devos, 2014). In general, commitment can be defined as a high level of attachment to something, which can drive someone to invest personal resources such as effort, time and any other resources like money (Moses, Admiraal, Amanda, Berry \& Saab, 2019; Tyree Jr, 1996). In the context of student teachers as the subject of this study, commitment can be associated with the excitement to become teachers, one of which evidence can be seen from their decision to select the teacher education faculty as the first choice in their university admission.

Furthermore, some researchers have identified various dimensions of commitment (Moses, Admiraal, Berry \& Saab, 2019). In this paper, student teachers' commitment refers to the four different levels of commitment that has been conceptualised by Pop and Turner (2009, as cited in 
Moses, Admiraal, Amanda, Berry \& Saab, 2017). They are 1) committed passionate, 2) committed compromiser, 3) undecided and 4) uncommitted. Simply, committed passionate student teachers are the ones who wholeheartedly commit to becoming teachers, while committed compromisers feel that becoming teachers is not their first dream job but are willing to join the teaching occupation. Furthermore, undecided is used to define those who are unsure whether they will become teachers, whereas uncommitted student teachers are the ones who do not have any willingness and interest to consider teaching as their future job. Instead, they want to seek a totally different career path.

Several factors have been associated with pre-service teachers' commitment to teaching. Gender as one of the personal factors, for instance, has been found to be a determining variable in explaining some differences in student teachers' commitment to teaching, although the findings could be considered inconclusive. A research study in Nigeria conducted by Maliki (2013), for instance, suggests that female student teachers show a firmer welcoming standpoint towards teaching compared to males. Similarly, Belgian female student teachers have also been found to have bigger intentions than males in the teaching profession (Rots, Aelterman \& Devos, 2014). However, the study of Triyanto and Handayani (2016) in Indonesia shows that male teachers are interestingly found to have better intentions in becoming teachers than female teachers. In line with this, an old study conducted by Bacon and Finnemann (1992) suggested that, in the Spanish context, females had an unexpectedly stronger instrumental motivation.

Similarly, research on student teachers' commitment to enrol in a teacher education programme and to the teaching in Indonesia has not yet been explored comprehensively. Therefore, research on these two major issues is of high importance in the Indonesian context, especially focussing on the types of motivation and the level of commitment of future teachers in Indonesian universities, under MoRA and MoEC, both public and private. Furthermore, as in the context of Indonesia the teaching profession in lower levels of schooling is still dominated by female teachers; gender is also another main issue in this study. Data from the MoEC, the Republic of Indonesia, show that there are 1,015,649 female teachers and only 456,957 male teachers. By this fact, it is also important to analyse whether more female student teachers have intrinsic motivation and are committed passionately, which is the highest level of commitment to become teachers.

In summary, there are two main research questions proposed in this study. The first one deals with the dominant motivation of English student teachers and that according to gender and types of university. The second one concerns the level of English student teachers' commitment according to gender and university types. Two types of motivations, instrumental and integrative, are used to identify the motivations of student teachers, whereas four levels of commitment are included in distinguishing student teachers' level of commitment, in which two background variables, namely gender and types of the university, are included.

\section{Methods}

\subsection{The design and subject}

In this study, a quantitative approach was employed to reach the subjects of the study, English student teachers in Jakarta, Banten, Surakarta, Makassar, Gorontalo and Lombok representing Java and outside Java islands in Indonesia. A contact person in each area was appointed in approaching the subjects, which accounted for 328 participants (F: 260, M: 67) selected using a non-probability sampling technique simply, i.e., convenience sampling. This was because this study was not intended to test a hypothesis, but to explore the types of motivation and the level of commitment of the 
subjects who came from both public and private universities under the supervision of MoEC and MoRA, which is provided in detail in Table 1.

Table 1. The number of participants according to the university type

\begin{tabular}{lcc}
\hline Type of the university & Frequency & Percentage (\%) \\
\hline Public University & 112 & 34 \\
Private University & 50 & 15 \\
Public Islamic University & 137 & 42 \\
Private Islamic University & 29 & 9 \\
Total & 328 & 100 \\
\hline
\end{tabular}

A public university refers to public universities under MoEC, while a private university refers to private universities under the same ministry. Furthermore, public Islamic university refers to public Islamic universities under MoRA, whereas private Islamic university are public Islamic university supervised by MoRA.

\subsection{The instrument}

The data on student teachers' motivation and commitment were collected through a questionnaire, which was developed based on the theory of motivation developed by Gardner and Lambert (1972). As has been indicated earlier, motivation in this study is divided into two, namely integrative and instrumental motivation. There were 14 items in the motivation questionnaire, which were equally distributed between the integrative and instrumental and measured in yes and no questions. Two examples of the integrative one are whether enrolling in the English Education Department will enable participants to appreciate English art and literature and whether it is their interest and determination, while those of the instrumental are whether registering at the English Education Department will help them in getting a well-paid and respectful occupation and whether it will help them achieve more in their lives.

Next, the level of commitment to teaching was measured using the approach introduced by Pop and Turner (2009, as cited in Moses, Admiraal, Amanda, Berry \& Saab, 2017), which consists of four levels: committed passionate, committed compromiser, undecided and uncommitted. Only three questions were included dealing with the participants' future careers upon their graduation and their vision on teaching, each was provided four options indicating the level of commitment. Concerning career, for instance, the options were (1) to become teachers (committed passionate), (2) to make the teaching profession as an alternative (committed compromiser), (3) not to choose the teaching profession and view it and a stepping stone (undecided) and (4) not willing to become a teacher (uncommitted). The decision to include only three items was to ensure that the subjects would fill in the questionnaire since it took only a few minutes to complete it. Moreover, some experts (Igarashi, 2019; Quispe-Tintaya, 2017; Robinson, 2018) have previously validated the use of only three items in a scale and thus the use of only three items to measure student teachers' commitment in this study is supported. 
The questionnaire was previously validated through an expert's judgment, which was added with a multi-factor confirmatory factor analysis (CFA) to check both the validity and reliability of the instrument. Since the scale of commitment consisted of only three questions, the CFA for the items of motivation (integrative and instrumental) and commitment was run together at the same time. The result shows that the theoretical construct fit the data well (see Figure 1) and thus the questionnaire is both valid and reliable.

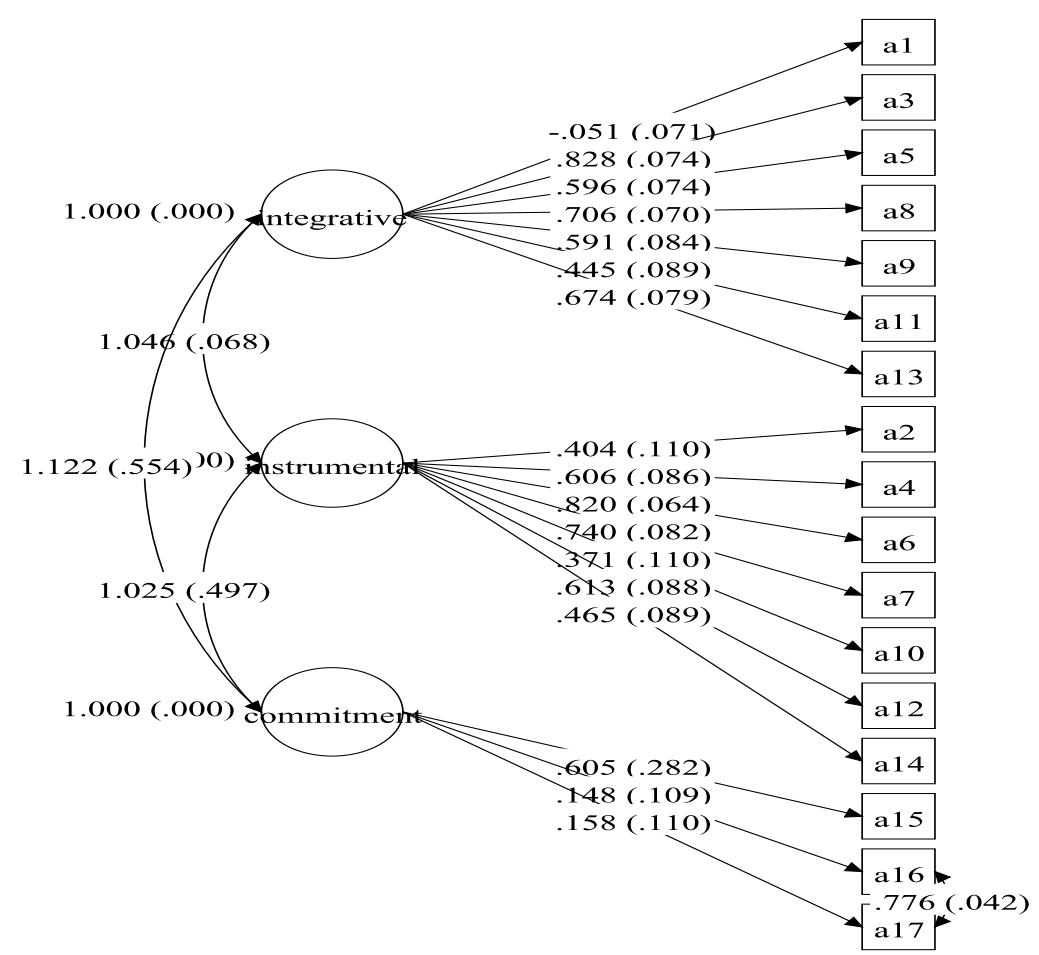

Figure 1. The result of multi-factor confirmatory factor analysis

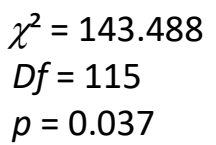

RMSEA (root mean square error of approximation) estimate $=0.028$

Probability RMSEA $<=0.05=0.998$

Nevertheless, it is good to acknowledge that there is one item dealing with integrative motivation and two items of commitment which should be dropped but were kept in this study due to the the acceptable overall indices of all three scales (integrative, instrumental and commitment) and also the limited number of items included. Finally, the questionnaire was distributed online in via Google Forms to reach the subjects of the study and ethical research practice was strictly followed to protect the participants' safety, privacy and confidentiality. 


\subsection{Data analysis}

For the data analysis, descriptive analysis was used to understand the number of student teachers having different types of motivation and levels of commitment. Next, the data were then cross-tabulated according to two background characteristics to observe some differences between motivation and level of commitment to teaching according to gender and four types of university (public university, private university, public Islamic university and private Islamic university).

\section{Findings}

\subsection{Student teachers' motivation}

\subsubsection{Student teachers' motivation in general}

The theory previously discussed that motivation can be categorised into two, instrumental and integrative. This section will explain students' motivation in general and according to background characteristics. This descriptive statistic is intended to provide a general view of student motivation.

Table 2. Students' motivation

\begin{tabular}{lcc}
\hline & Frequency & Percentage \\
\hline Integrative & 183 & 56 \\
Instrumental & 145 & 44 \\
Total & 328 & 100 \\
\hline
\end{tabular}

The findings, as indicated in Table 2, show that there are many more participants who have integrative motivation. There are 183 participants, or $56 \%$, compared to 145 participants who have instrumental motivation. However, this difference is not very much, as it accounts for just above $10 \%$. This finding is a bit surprising since only less than $60 \%$ of the participants are indeed wishing to be teachers from the very beginning, while others enrol in English teacher education departments because of other reasons.

\subsubsection{Students' motivation according to gender}

The findings of the descriptive statistics on students' motivation according to gender reveal that the percentage of both males and females having the integrative motivation to become teachers is slightly different. As can be seen in Table 3, as many as 41 (60\%) males compared to 145 (55\%) females were found to have integrative motivation. This means that the percentage of females having integrative motivation is slightly lower than that of males, which is surprising. 
Table 3. Types of motivation according to gender

\begin{tabular}{lccc}
\hline & \multicolumn{2}{c}{ Types of motivation (\%) } & \multirow{2}{*}{ Total } \\
\cline { 2 - 3 } & Integrative & Instrumental & \\
\cline { 2 - 3 } Male & & & \\
Female & $41(60 \%)$ & $26(40 \%)$ & 67 \\
Total & $142(55 \%)$ & $118(45 \%)$ & 260 \\
\hline
\end{tabular}

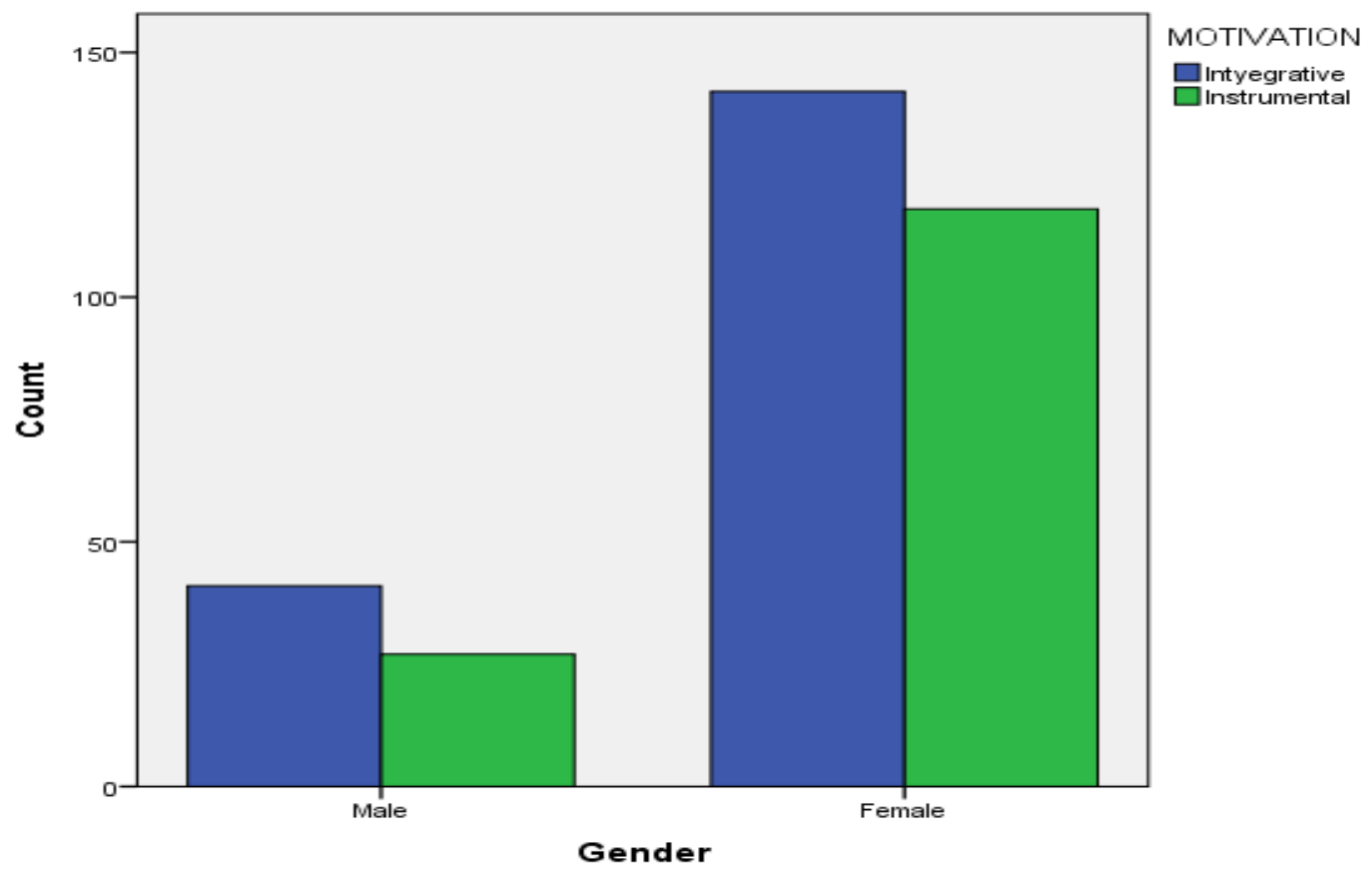

Figure 2. Types of motivation according to gender

Furthermore, concerning those having instrumental motivation, Table 2 displays that the percentage of females having instrumental motivation is $5 \%$ higher than that of males. However, it is important to note that within each gender, the percentage of student teachers with integrative motivation is higher compared to those who have instrumental motivation as can be seen from Figure 2. For males, for instance, the number of those who have integrative motivation reached 42 compared to 26 participants who have instrumental motivation. Similarly, the number of female participants who have integrative motivation is accounted for at 142 compared to 118 who have instrumental motivation.

However, it is important to note that the difference is not big. As can be seen in Figure 2, the gap between the integrative and instrumental is not that wide, indicating that there is a considerable number of student teachers, both males and females, who have enrolled in the English Education Department without integrative motivation to become teachers. 


\subsubsection{Students' motivation according to university types}

Table 4 displays the types of motivation according to the four university categories used in this study.

Table 4. Students' motivation according to university types

\begin{tabular}{llcc}
\hline \multirow{2}{*}{ No } & Type of university & \multicolumn{2}{c}{ Type of motivation } \\
\cline { 3 - 4 } & & Integrative & Instrumental \\
\hline 1. & Public University & $67(60 \%)$ & $45(40 \%)$ \\
2. & Private University & $29(58 \%)$ & $21(42 \%)$ \\
3. & Public Islamic University & $6950 \%$ & $68(50 \%)$ \\
4. & Private Islamic University & $18(62 \%)$ & $11(38 \%)$ \\
\hline
\end{tabular}

With regard to all types of universities, the descriptive analysis as presented in Table 4 and Figure 3, also indicate that more participants have integrative motivation. For instance, 67 participants had integrative motivation compared to 45 who had an instrumental one in the public university. Furthermore, for the case of Islamic universities, there are as many as $62 \%$ of English student teachers in the private Islamic university who have integrative motivation which is the highest percentage compared to other types of universities. Surprisingly, the number of those having integrative and instrumental motivation in public Islamic universities is almost the same, at 69 and 68, respectively, indicating a significant number of English student teachers in state Islamic universities who might not want to truly become teachers when they enrolled in the department.

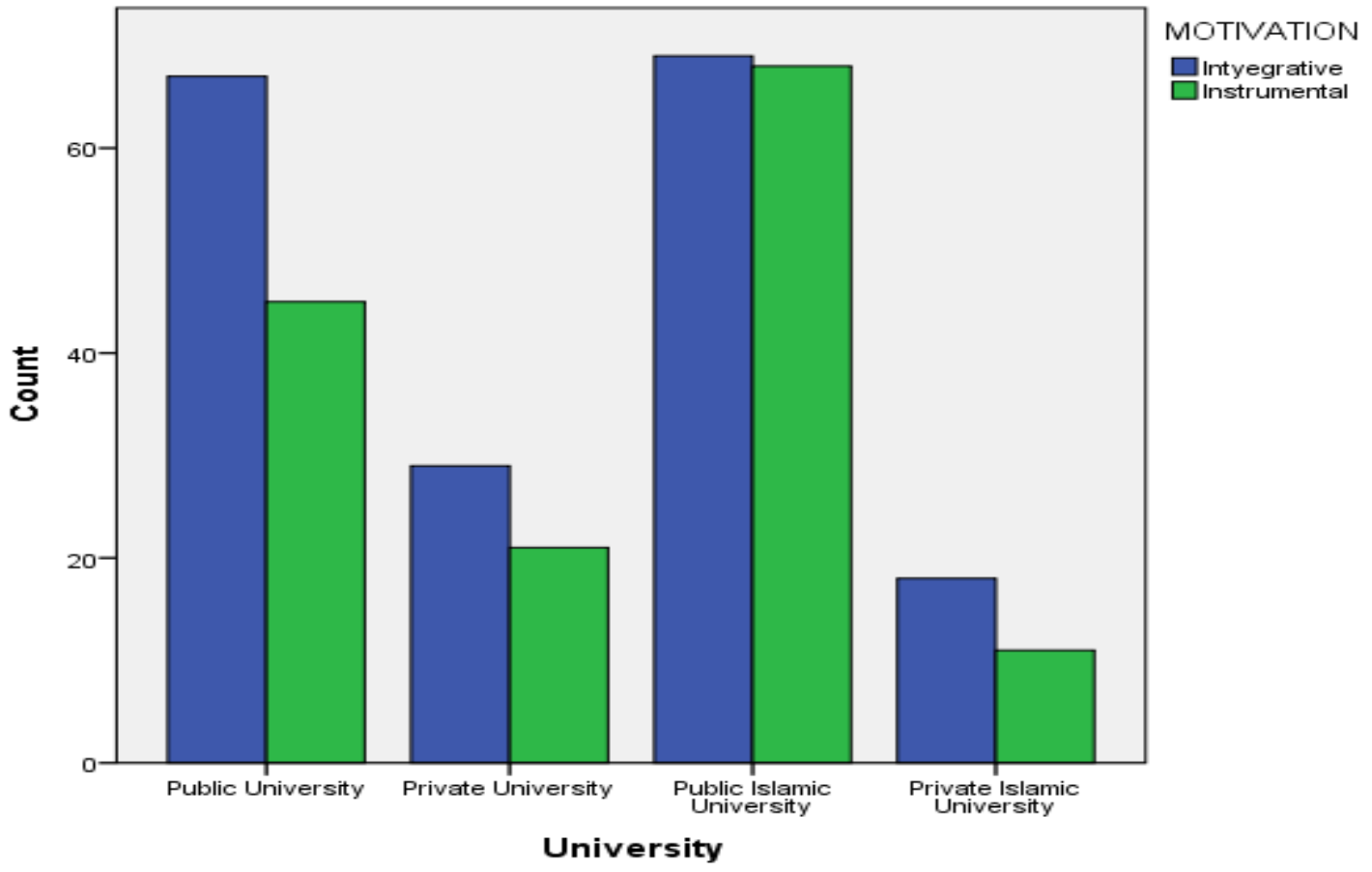

Figure 3. Types of motivation according to university type 


\subsection{Level of commitment}

\subsubsection{Level of commitment in general}

Similar to the student teachers' motivation, their commitment will also be described in general representing all participants in the study and according to their gender and types of university. As discussed in the introduction of this paper, students' level of commitment to teaching is divided into four, namely committed passionate, committed compromiser, undecided and uncommitted, in which the most expected one is committed passionate.

Table 5. Student teachers' level of commitment to teaching

\begin{tabular}{lcc}
\hline & Frequency & Percentage \\
\hline Committed passionate & 145 & 44.2 \\
Committed Compromiser & 126 & 38.4 \\
Undecided & 24 & 7.3 \\
Uncommitted & 33 & 10.1 \\
Total & 328 & 100 \\
\hline
\end{tabular}

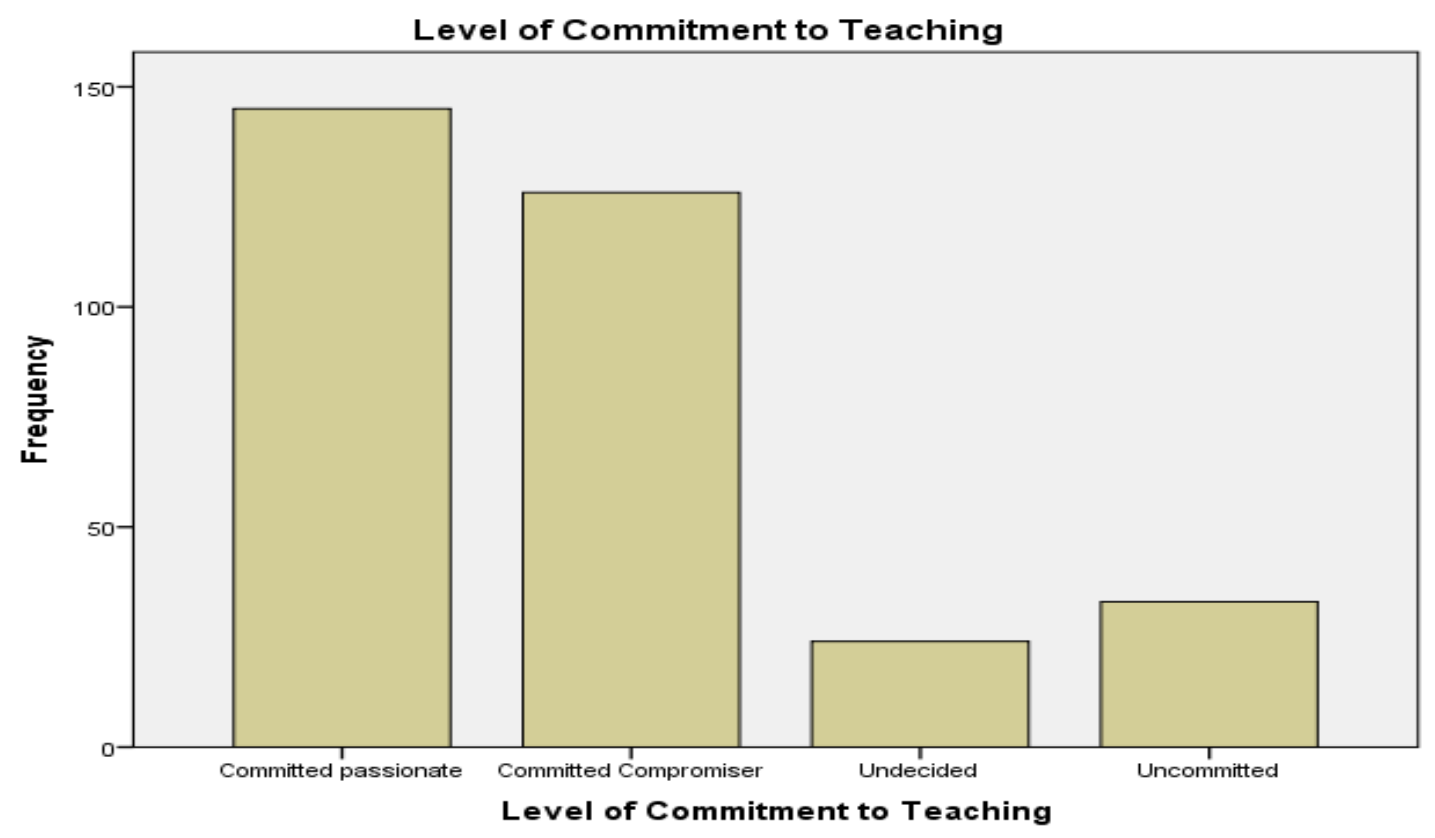

Figure 4. Student teachers' level of commitment to teaching

From both Table 5 and Figure 4, it can be seen that the highest percentage belongs to committed passionate, reaching 145 (44\%) participants, which means that nearly half of the participants wanted to become teachers from the beginning and therefore decided to enrol in the English Education Department. This is then followed by the number of those who are committed compromiser (126 participants), which is only around 6\% lesser than the figure of committed 
passionate. In other words, $38 \%$ of the participants have finally chosen the the English Education Department as their major since their first choice is not met.

Furthermore, as expected, the number of those who are undecided and uncommitted is much lower compared to that of committed passionate and committed compromiser. The total of both undecided and uncommitted, who will not likely become teachers in the future, is slightly less than $20 \%$. However, it is interesting to note that there are more uncommitted (10\%) than undecided (7\%) student teachers in this study indicating a considerable number of English student teachers who do not want to become teachers after they finish their study.

Furthermore, two background characteristics, namely gender and types of the university, are included in this study and therefore it is compelling to examine the level of commitment according to these two background variables.

\subsubsection{Level of commitment according to gender}

In this study, the number of female participants outweighs that of males, 260 and 68, respectively. Therefore, it is important to pay attention to the percentage in each category in both males and females so that a fair comparison can be made.

Table 6 reveals that the highest proportion among various categories in the data is shown by committed passionate females, at $47 \%$ (121 participants), suggesting that a considerably high proportion of female participants who are committed to the teaching profession from the start continue their higher education. This figure is more than $10 \%$ higher than that of males since only $35 \%$ of them are committed passionate. Moreover, the highest percentage of the male is committed compromiser showing that there are more male participants who finally decided to enrol in the English Education Department although it was not their first choice.

Table 6. Student teachers' level of commitment to teaching according to gender

\begin{tabular}{lcccc|c}
\hline Gender & \multicolumn{2}{c}{ Level of commitment to teaching (frequency / percentage) } & \multicolumn{2}{c}{ Total } \\
\cline { 2 - 6 } & $\begin{array}{l}\text { Committed } \\
\text { passionate }\end{array}$ & $\begin{array}{c}\text { Committed } \\
\text { compromiser }\end{array}$ & Undecided & Uncommitted & \\
\hline Male & $24(35 \%)$ & $26(38 \%)$ & $5(8 \%)$ & $13(19 \%)$ & $68(100 \%)$ \\
Female & $121(47 \%)$ & $100(38 \%)$ & $19(7 \%)$ & $20(8 \%)$ & $260(100 \%)$ \\
\hline
\end{tabular}

Furthermore, the figure of undecided participants for both males (8\%) and females (7\%) stands as the lowest compared to the other three levels of commitment. Concerning the percentage of uncommitted English student teachers, the data display that nearly one-fourth of male participants are not ready to become teachers and therefore will find other professions. There are also uncommitted female participants in this study, yet the number is only a half, nearly one-eighth.

\subsubsection{Level of commitment according to university types}

In addition to gender, it is also relevant to examine whether the level of commitment to teaching among the four different categories of universities is different. This is also because one background variable included in this study is the type of university. Table 7 provides detailed information on this suggesting that in each of the four types of university, committed passionate 
reaches more than $40 \%$, in which public Islamic university is the highest, at $48 \%$. However, it is a bit surprising to see that the highest percentage among various categories in the data is committed compromiser belonging to the private Islamic university standing at $52 \%$.

Table 7. Student teachers' level of commitment to teaching according to gender

\begin{tabular}{lcccc}
\hline \multicolumn{1}{c}{ Type of university } & \multicolumn{4}{c}{ Level of commitment to teaching } \\
\cline { 2 - 5 } & \multicolumn{1}{c}{ Committed passionate } & Committed compromiser & Undecided & Uncommitted \\
\hline Public University & $45(40 \%)$ & $42(37 \%)$ & $12(11 \%)$ & $13(12 \%)$ \\
Private University & $23(46 \%)$ & $14(28 \%)$ & $4(8 \%)$ & $9(18 \%)$ \\
Public Islamic University & $65(48 \%)$ & $55(40 \%)$ & $7(5 \%)$ & $10(7 \%)$ \\
Private Islamic University & $12(41 \%)$ & $15(52 \%)$ & $1(3 \%)$ & $1(3 \%)$ \\
\hline
\end{tabular}

Furthermore, as expected, the percentages of undecided and uncommitted are all below $20 \%$, with uncommitted in the private university being the highest (18\%). Moreover, it is important to note that there is only one (3\%) student teacher who is undecided and uncommitted from the private Islamic university standing as the lowest percentage. In short, in all types of universities, there are many more participants who wanted to enrol in the English education department because they want to become teachers in the future except the private Islamic university, which has slightly more than $50 \%$ of committed compromiser.

\section{Discussion}

The findings in this study reveal that the number of English student teachers who have integrative motivation in this study is slightly higher than those having the instrumental one, at $56 \%$ and $44 \%$, respectively. Thus, this finding is in line with the studies of Low, Lim, Ch'ng and Goh (2011) and Teh, Sulaiman and Yusoff (2018), which have also found a higher number of student teachers who have intrinsic motivation.

However, it is important to note that $44 \%$ of the respondents in this study have instrumental motivation, which means that they do not have a genuine intention to become teachers. Instead, they likely decided to enrol in the English Education Department because of some other reasons, such as the respectful status of the teaching profession and the higher level of salary, thanks to the certification programme. Yet, this is a big homework for teacher education institutes to ensure the quality of their inputs, especially on their genuine motivation to become teachers. Moreover, Masbirorotni et al. (2020) stated that up until now the government has not yet regulated the criteria of admission for student teachers to enrol at the teacher education institutions.

With regards to gender differences, the finding in this study reveals that a high number of student teachers having intrinsic motivation can be observed from both males and females. However, compared with those having instrumental motivation in each gender, the descriptive analysis finds a slightly higher percentage of males, at $60 \%$ compared to females at only $55 \%$. Although this is a bit surprising since the teaching profession has been long considered to be a feminine profession and therefore females are considered to fit in the best, this finding corresponds to an old study carried out by Bacon and Finnemann (1992), which showed that female students at university level had the stronger instrumental motivation and not the integrative one. Moreover, this study also supports a 
more recent study conducted by Triyanto (2016) which indicates that male teachers are more motivated than female teachers.

Concerning the differences in student teachers' motivation according to the types of university, this study suggests a higher proportion of student teachers having integrative motivation in the four categories of the university. It has to be admitted that studies on this kind of comparison are not easy to find. Yet, some studies on the comparison of English teachers' motivation toward teaching English between private and public schools could be relevant to enrich the discussion of this study. Alipour (2018), for instance, shows that teachers in private institutions are found to have better motivation than public school teachers. Although not exactly the same, the findings in the study can be used as a reference to find some strategies to keep their motivation when entering the real teaching profession.

Furthermore, the findings on student teachers' level of commitment suggest that there is generally a higher proportion of participants who are committed to becoming teachers in the future, in which $44 \%$ are committed passionate and $38 \%$ are committed compromiser. This means that the English Education Department where the participants of this study continue their higher education has a large number of students who have decided to enter the teaching profession in the future.

Following the characteristic of committed student teachers explained by Moses, Admiraal, Amanda, Berry \& Saab (2019) and Tyree (1996), more participants in this study thus can be considered to have built an attachment to teaching and therefore are willing to invest their time, energy and necessary resources for the success of their study and their professional career in the future. Among those who are committed, more female participants than males are found to be committed passionate, at $47 \%$ and $35 \%$, respectively. Thus, the finding, in this case, supports previous findings (Maliki, 2013; Rots, Aelterman \& Devos, 2014) showing the better commitment of female student teachers in the teaching profession.

Furthermore, although small, there is a considerable percentage of participants who are undecided (7\%) and uncommitted (10\%). Moreover, the percentage of those who are committed compromisers, whose first choice was not teaching but have finally decided to enroll in the teaching profession, is considerably high, at nearly one fourth. This finding is in line with the relatively high percentage of participants in this study who have the instrumental motivation, at $44 \%$.

\section{Conclusion and recommendation}

This study has raised two main questions, namely English student teachers' motivation and level of commitment to teaching and those according to their gender and types of the university they study. Using descriptive statistics, the study shows that in general, $56 \%$ of participants have the integrative motivation, in which $60 \%$ of males compared to $55 \%$ of females are found to have this type of motivation. With regard to the types of university, the data reveal that all university types have more than $50 \%$ of student teachers who have integrative motivation, except the state Islamic university which has exactly $50 \%$.

Concerning the level of commitment to teaching, the findings of the study suggest that the highest percentage among the four levels of commitment is, as expected, committed passionate at $44 \%$ which is then followed by committed compromiser at $38 \%$. From the gender perspective, female student teachers in this study are found to have a higher number of committed passionate, $47 \%$, 
compared to $35 \%$ of males who have the same level of commitment. Finally, the highest percentage of committed passionate, the most important level of commitment to teaching, is public Islamic university, at $48 \%$.

Thus, the findings of this study suggest a slightly higher figure of those who have integrative motivation while only less than $50 \%$ of the participants in this study are found to be committed passionate, the expected level of commitment, although combined with those who are committed compromiser, reached $82 \%$. Thus, the findings in this study imply necessary actions from both the government and the teacher education institutions. The role of the government is required to establish a standard policy to recruit teacher candidates from the admission process so that better inputs can be ensured. Moreover, it is known that student teachers take exactly the same examination as others when they enrol in teacher education institutions.

Furthermore, the role of teacher education institutions is also paramount to help maintain and enhance their student teachers' motivation and commitment to teaching. Moreover, some previous studies have also supported the notion since student teachers' motivation and intention to enter the teaching profession have increased during their study in the teacher education faculties (Rots, Kelchtermans \& Aelterman, 2012). Regardless of the types of university, the first and foremost is that the institutions should carry out some activities to maintain the motivation and commitment of their motivated and committed student teachers and to increase the motivation and commitment of those who are in the level of undecided and uncommitted. In this case, mentor support is one factor that can be initiated by the institutions since some studies have shown its positive effect (e.g., Christophersen, Elstad, Solhaug \& Turmo, 2016; Durksen \& Klassen, 2012). Mentoring activities from senior student teachers to their juniors can provide an enabling and motivating environment for the juniors to build stronger motivation and commitment to enter the teaching profession after their graduation.

\section{References}

Alipour, S. (2018). Comparison of private-institute and public-school English teachers' motivation toward teaching English in Iran. Cypriot Journal of Educational Science, 13(4), 631-644. doi: $10.18844 /$ cjes.v13i4.3600

Astika, G. (2014). Reflective teaching as alternative assessment in teacher education: A case study of pre-service teacher. TEFLIN Journal, 25(1), 16-32. doi:10.15639/teflinjournal.v25i1/16-32

Azkiyah, S. N. \& Mukminin, A. (2017). In search of teaching quality of EFL student teachers through teaching practicum: lessons from a teacher education program. Center for Educational Policy Studies Journal, 7(4), 105-124. Retrieved from https://www.researchgate.net/publication/322026733_In_Search_of_Teaching_Quality_of_ EFL_Student_Teachers_through_Teaching_Practicum_Lessons_from_a_Teacher_Education_ Program

Bacon, S. \& Finneman, M. (1992). Sex differences in self-reported beliefs about foreign-language learning and authentic oral and written input. Language Learning, 42, 471-495. doi:10.1111/j.1467-1770.1992.tb01041.x 
Bruinsma, M. F. \& Canrinus, E. T. (2012). The factors influencing teaching (FIT)-choice scale in a Dutch teacher education program. Asian-Pacific Journal of Teacher Education, 40(3), 249-269. doi:10.1080/1359866X.2012.700043

Christophersen, K. A., Elstad, E., Solhaug, T. \& Turmo, A. (2016). Antecedents of student teachers' affective commitment to the teaching profession and turnover intention. European Journal of Teacher Education, 29(3), 270-286. doi:10.1080/02619768.2016.1170803

Creemers, B. \& Kyriakides, L. (2008). The dynamics of educational effectiveness. A contribution to policy, practice and theory in contemporary schools. London: Routledge Taylor \& Francis Group.

Deci, E. L. (1975). Intrinsic motivation. Boston: Springer. doi:10.1007/978-1-4613-4446-9

Durksen, T. \& Klassen, R. (2012). Pre-service teachers' weekly commitment and engagement during a final training placement: a longitudinal mixed methods study. Educational \& Child $\begin{array}{llll}\text { Psychology, 29(4), } & \text { 32-46. } & \text { Retrieved }\end{array}$ https://www.researchgate.net/publication/263876672_Preservice_teachers'_weekly_commitment_and_engagement_during_a_final_training_placeme nt_A_longitudinal_mixed_methods_study

Ellis, R. (1994). The study of second language acquisition. Oxford, UK: Oxford University Press.

Gardner, R. C. \& Lambert, W. E. (1972). Attitudes and motivation in second language learning. New York: Newbury House Publishers. doi:10.1016/B0-08-044854-2/00625-8

Heinz, M. (2015). Why choose teaching? An international review of empirical studies exploring student teachers' career motivations and levels of commitment to teaching. Educational Research and Evaluation, 21(3), 258-297. doi:10.1080/13803611.2015.1018278

Igarashi, T. (2019). Development of the Japanese version of the three-item loneliness scale. $B M C$ Psychology, 7(1), 1-8. https://doi.org/10.1186/s40359-019-0285-0

Jiying, H. \& Hongbiao, Y. (2016). Teacher motivation: Definition, research development and implications for teacher. Cogent Education, 3, 3(1). doi:10.1080/2331186X.2016.1217819

Klassen, R. \& Chiu, M. M. (2011). The occupational commitment and intention to quit of practicing and pre-service teachers: influence of self-efficacy, job stress, and teaching context. Contemporary Educational Psychology, 36(2), 114-129. doi:10.1016/j.cedpsych.2011.01.002

Konig, J., Rothland, M., Tachtsoglou, S. \& Klemenz, S. (2016). Change of teaching motivations among pre-service teachers in Austria, Germany, and Switzerland: do in-school opportunities to learn matter? International Journal of Higher Education, 5(3), 195-210. doi:10.5430/ijhe.v5n3p91

Low, E. L., Lim, S. K., Ch’ng, A. \& Goh, K. C. (2011). Pre-service teachers' reasons for choosing teaching as a career in Singapore. Asian Pacific Journal of Education, 31(2), 195-210. doi:10.1080/02188791.2011.567441

Low, E., Ng, P., Hui, C. \& Cai, L. (2017). Teaching as a career choice: triggers and drivers. Australian Journal of Teacher Education, 42(2). doi:10.14221/ajte.2017v42n2.3

Maliki, A. E. (2013). Attitudes towards the teaching profession of students from the faculty of education, Niger Delta University. International Journal of Social Science Research, 1, 11-18. 
Retrieved from https://www.semanticscholar.org/paper/Attitudes-towards-the-TeachingProfession-of-from-Maliki/99327869c567dffa1bef7338cea7ce3e40b3a6aa

Masbirorotni, M., Mukminin, A., Muhaimin, Habibi, A., Haryanto, E., Marzul, H., ... Kamil, D. (2020). Why student teachers major in English education: an analysis of motives for becoming future teachers. Journal of Elementary Education, 13(4), 429-452. doi:10.18690/rei.13.4.429452.2020

Moses, I., Admiraal, W., Berry, A. \& Saab, N. (2019). Student-teachers' commitment to teaching and intentions to enter the teaching profession in Tanzania. South African Journal of Education, 39(1). doi:10.15700/saje.v39n1a1485

Moses, I., Admiraal, W., Berry, A. \& Saab, N. (2017). Who wants to become a teacher? Typology of student-teachers' commitment to teaching. Journal of Education for Teaching, 43(4), 444457. doi:10.1080/02607476.2017.1296562

Muijs, D. \& Reynolds, D. (2011). Effective teaching: evidence and practice (3rd ed.). Thousand Oaks, CA: SAGE.

Pinder, C. C. (1998). Work motivation in organizational behavior. Upper Saddle River, NJ: Prentice Hall.

Quispe-Tintaya, W. (2017). 乳鼠心肌提取 HHS public access. Physiology \& Behavior, 176(3), 139-148. doi:10.1177/1362361313487028.Three-item

Raufelder, D. \& Hoferichter, F. (2015). Development and Validation of the Teacher and Motivation (TEMO) scale: a self-report measure assessing students' perceptions of liked and disliked teachers as motivators. International Journal of School \& Educational Psychology, 3(2), 97106. doi:10.1080/21683603.2014.966228

Robinson, M. A. (2018). Using multi-item psychometric scales for research and practice in human resource management. Human Resource Management, 57(3), 739-750. https://doi.org/10.1002/hrm.21852

Rots, I., Aelterman, A. \& Devos, G. (2014) Teacher education graduates' choice (not) to enter the teaching profession: does teacher education matter?, European Journal of Teacher

Education, 37(3), 279-294. doi: 10.1080/02619768.2013.845164

Rots, I., Kelchtermans, G. \& Aelterman, A. (2012). Learning (not) to become a teacher: A qualitative analysis of the job entrance issue. Teaching and Teacher Education, 28(1), 1-10. doi:10.1016/j.tate.2011.08.008

Tang, S. Y. F., Wong, P. M., Wong, A. K. Y. \& Cheng, M. M. H. (2018). What attracts young people to become teachers? A comparative study of pre-service student teachers' motivation to become teachers in Hong Kong and Macau. Asia Pacific Education Review, 19(3). doi:10.1007/s12564-018-9541-x

Teh, K. S. M., Sulaiman, A. A. \& Yusoff, N. M. R. N. (2018). Instrumental motivation orientation vs integrative among Arabic language and literature diploma students. International Journal of Academic Research in Business and Social Sciences, 8(10), 308-314. doi:10.6007/IJARBSS/v8i10/4736 
Triyanto \& Handayani, R. (2016). Teacher motivation based on gender, tenure and level of education. The New Educational Review, 45(3). doi:10.15804/tner.2016.45.3.16

Tyree Jr, A. K. (1996). Conceptualizing and measuring commitment to high school teaching. The Journal of Educational Research, 89(5), 295-304. Retrieved from http://www.jstor.org/stable/27542047 